\title{
MORPHOLOGICAL PARAMETERS OF THE DIGESTIVE SYSTEM OF RUSSIAN STURGEON (ACIPENSER GUELDENSTAEDTII BRANDT \& RATZEBURG, 1833) FRY UNDER EXPOSURE TO DRY BAKER'S YEASTS AS AN ADDITIVE TO THE BASIC FEED
}

M. Simon, seemann.sm@gmail.com, Institute of Fisheries NAAS, Kyiv Yu.Zabytivskyi, yurafish@ukr.net, Lviv Experimental Station of Institute of Fisheries NAAS, Velykyi Lyubin

I. Hrytsyniak, info@if.org.ua, Institute of Fisheries NAAS, Kyiv

L. Dragan, dragan I@ukr.net, Institute of Fisheries NAAS, Kyiv

Purpose. To analyze the effect of different concentrations of dry inactivated baker's yeasts on the morphological parameters of the digestive system of Russian sturgeon fry, using enterocytes and hepatocytes as an example, to determine the optimal concentrations that could be used as a part of starter feeds when growing the above mentioned fish species in recirculating aquaculture systems (RAS).

Methodology. Classical histological methods were used in the study. Russian sturgeon fry were sampled every 7 days from the beginning of experimental feeding. After anesthesia, they were placed in a Buen solution (15 parts of a saturated aqueous solution of picric acid, 5 parts of formalin, 1 part of acetic acid) for 24 hours. After rinsing, the specimens were stored in $70 \%$ ethanol $\left(\mathrm{C}_{2} \mathrm{H}_{5} \mathrm{OH}\right)$. Specimens were processed through alcohols and embedded in paraffin in accordance with the generally accepted technique. Histologic sections were stained with hematoxylin $\left(\mathrm{C}_{16} \mathrm{H}_{14} \mathrm{O}_{6} .3 \mathrm{H}_{2} \mathrm{O}, \mathrm{M}\right.$. w. 356.33) and eosin $\left(\mathrm{C}_{20} \mathrm{H}_{8} \mathrm{Br}_{4} \mathrm{O}_{5}\right.$, M. w. 647.89052).

Findings. The study demonstrated the effect of different concentrations of baker's yeasts in the composition of the starter feed for Russian sturgeon on the morphometric parameters of their digestive system using the example of enterocytes and hepatocytes. The positive effect of dry baker's yeasts, which is manifested in an increase in the absorption of enterocyte surface and an improvement in the locality in glycocalyx, both for enzymes and symbiotic microorganisms playing an active role in extracellular digestion, has been shown. In addition, no toxic effect of a high concentration of baker's yeasts in the diet on the organism of Russian sturgeon fry was registered.

Scientific novelty. For the first time the analysis of the effect of different concentrations of inactivated baker's yeast, as part of the diet of Russian sturgeon fry, on the morphometric parameters of its digestive system has been performed.

Practical value. Dry inactivated baker's yeasts were proved to be advisable to add to the starter feed for the Russian sturgeon as a biologically active dietary supplement because they have a positive effect on fish digestive system.

Key words: Russian sturgeon fingerling, inactivated baker's yeast, digestive system, enterocytes, hepatocytes, started diet for fish.

(C) M. Simon, Yu. Zabytivskyi, I. Hrytsyniak, L. Dragan, 2019 
MORPHOLOGICAL PARAMETERS OF THE DIGESTIVE SYSTEM OF RUSSIAN STURGEON (ACIPENSER GUELDENSTAEDTII BRANDT \& RATZEBURG, 1833) FRY UNDER EXPOSURE TO DRY BAKER'S YEASTS AS AN ADDITIVE TO THE BASIC FEED

\section{МОРФОЛОГІЧНІ ПАРАМЕТРИ ТРАВНОЇ СИСТЕМИ МОЛОДІ РОСІЙСЬКОГО OCETPA (ACIPENSER GUELDENSTAEDTII BRANDT \& RATZEBURG, 1833) ЗА ДІї ПЕКАРСЬКИХ ДРІЖДЖІВ, ЗГОДОВУВАНИХ 3 ОСНОВНИМ КОРМОМ}

М. Ю. Симон, seemann.sm@gmail.com, Інститут рибного господарства НАAН, М. Київ

Ю. М. Забитівський, yurafish@ukr.net, Львівська дослідна станція IPГ НАAН, смт. Великий Любінь

І. І. Грициняк, info@if.org.ua, Інститут рибного господарства НАAН, м. Київ

л. П. Драган, dragan @@ukr.net, Інститут рибного господарства НАAН, м. Київ

Мета. Провести аналіз дії різних концентрацій сухих інактивованих пекарських дріжджів на морфологічні параметри травної системи молоді російського осетра на прикладі ентероцитів та гепатоцитів для встановлення оптимальних концентрацій, які могли б бути використані в складі стартових кормів, під час вирощування вищезгаданого виду риб в установках замкненого водопостачання (УзВ).

Методика. Для досягнення мети роботи були використані класичні гістологічні методи досліджень. Так, кожних 7 діб з початку експериментальної годівлі відбирали молодь російського осетра, яку після анестезії поміщали на 24 години в розчин Буена (15 частин насиченого водного розчину пікринової кислоти, 5 частин формаліну, 1 частина оцтової кислоти). Після ополіскування препарат зберігали у 70\%-му розчині етанолу $\left(\mathrm{C}_{2} \mathrm{H}_{5} \mathrm{OH}\right)$. Препарати переводили через спирти і заливали в парафін за загальноприйнятою методикою. Гістологічні зрізи забарвлювали гематоксиліном $\left(\mathrm{C}_{16} \mathrm{H}_{14} \mathrm{O}_{6} \cdot 3 \mathrm{H}_{2} \mathrm{O}\right.$, М. м. 356,33) та еозином (( $\mathrm{C}_{20} \mathrm{H}_{8} \mathrm{Br}_{4} \mathrm{O}_{5}$, M. w. 647.89052).

Результати. Продемонстровано вплив різних концентрацій пекарських дріжджів у складі стартового корму для російського осетра на морфометричні параметри його травної системи на прикладі ентероцитів та гепатоцитів. Виявлено позитивний вплив дріжджів, що проявляється у збільшенні всмоктувальної поверхні ентероцитів та покращенні локалітету у глікокаліксі як для ензимів, так і для симбіотичних мікроорганізмів, що відіграють активну роль у позаклітинному травленні. Одночасно, не зареєстровано токсичного едекту високої концентрації дріжджів в раціоні на організм молоді російського осетра.

Наукова новизна. Вперше здійснено аналіз впливу різних концентрацій інактивованих пекарських дріжджів у складі рачіону молоді російського осетра на морфометричні показники травної системи останнього.

Практична значимість. Доведено, що сухі інактивовані пекарські дріжджі дочільно вводити в стартові корми для російського осетра в якості біологічно активної добавки, оскільки вони справляють позитивний вплив на його травну систему.

Ключові слова: молодь російського осетра, інактивовані пекарські дріжджі, травна система, ентероцити, гепатоцити, стартові корми для риб.

\section{МОРФОЛОГИЧЕСКИЕ ПАРАМЕТРЫ ПИЩЕВАРИТЕЛЬНОЙ СИСТЕМЫ МОЛОДИ PУCСКОГО OCETPA (ACIPENSER GUELDENSTAEDTII BRANDT \& RATZEBURG, 1833) ПРИ ВОЗДЕЙСТВИИ ПЕКАРСКИХ ДРОЖЖЕЙ, СКАРМЛИВАЕМЫХ С ОСНОВНЫМ КОРМОМ}

М. Ю. Симон, seemann.sm@gmail.com, Институт рыбного хозяйства НАAН, г. Киев

ю. М. Забытивский, yurafish@ukr.net, Львовская опытная станция ИРХ НАAН, пгт Великий Любень

И. И. Грициняк, info@if.org.ua, Институт рыбного хозяйства НАAН, г. Киев

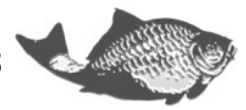




\section{Л. П. Драган, dragan I@ukr.net, Институт рыбного хозяйства НАAН, г. Киев}

Цель. Осуществить анализ воздействия различных концентраций сухих инактивированных пекарских дрожжей на морфологические параметры пищеварительной системы молоди русского осетра на примере энтероцитов и гепатоцитов для установления оптимальных концентраций, которые могли бы быть использованы в составе стартовых кормов при выращивании вышеупомянутого вида рыб в установках замкнутого водоснабжения (УЗВ).

Методика. Для достижения цели работы были использованы классические гистологические методы исследований. Так, каждые 7 дней с начала экспериментального кормления отбирали молодь русского осетра, которую после анестезии помещали на 24 часа в раствор Буэна (15 частей насыщенного водного раствора пикриновой кислоты, 5 частей формалина, 1 часть уксусной кислоты). После ополаскивания препарат хранили в 70\% растворе этанола ( $\left.\mathrm{C}_{2} \mathrm{H}_{5} \mathrm{OH}\right)$. Препараты проводили через спирты и заливали в парафин по общепринятой методике. Гистологические срезы окрашивали гематоксилином $\left(\mathrm{C}_{16} \mathrm{H}_{14} \mathrm{O}_{6} \cdot 3 \mathrm{H}_{2} \mathrm{O}\right.$, М.м. 356,33) и эозином $\left(\mathrm{C}_{20} \mathrm{H}_{8} \mathrm{Br}_{4} \mathrm{O}_{5}\right.$, М.м. 647.89052).

Результаты. Продемонстрировано влияние различных концентраций пекарских дрожжей в составе стартового корма для русского осетра на морфометрические параметры его пищеварительной системы на примере энтероцитов и гепатоцитов. Выявлено, положительное влияние дрожжей, проявляющееся в увеличении всасывающей поверхности энтероцитов и улучшении локалитета в гликокаликсе как для энзимов так и симбиотических микроорганизмов, которые играют активную роль во внеклеточном пищеварении. Кроме того, не был зарегистрирован токсический эффект высокой концентрации дрожжей в рационе на организм молоди русского осетра.

Научная новизна. Впервые осуществлен анализ влияния различных концентраций инактивированных пекарских дрожжей в составе рациона молоди русского осетра на морфометрические показатели его пищеварительной системы.

Практическая значимость. Доказано, что сухие инактивированные пекарские дрожжи целесообразно вводить в стартовые корма для русского осетра в качестве биологически активной добавки, поскольку они оказывают положительное влияние на его пищеварительную систему.

Ключевые слова: молодь русского осетра, инактивированные пекарские дрожжи, пищеварительная система, энтероциты, гепатоциты, стартовые корма для рыб.

\section{PROBLEM STATEMENT AND ANALYSIS OF LAST ACHIEVEMENTS AND PUBLICATIONS}

The digestive system of Russian sturgeon combines not only signs of cartilaginous (Chondrichthyes) and bony (Teleostei) fishes, but also batrachians (Anura, Salientia, Ecaudata). There are a number of species-specific characteristics inherent in their digestive system described in detail by D. A. Bednyakov and others [1-4]. First, it is the activity of enzymes in the intestinal mucosa, which are involved in membrane (perineal) digestion and its dependence on abiotic and biotic factors. Secondly, morphological characteristics of the microvilli of intestinal mucosa. Thirdly, the asynchronous development of the digestive tract, the formation of which is as follows: spiral intestine $\rightarrow$ colon $\rightarrow$ stomach. Thus, the formation of the digestive system in Russian sturgeon begins in the period of embryogenesis, and ends at an age of 40-50 days, in other words during the fry period of development. In the early ontogeny of this species, there is a close correlation between the development of the structure and function of the digestive system and food needs. Data on the functioning of the digestive system, in particular 
morphological parameters of the intestine and liver, are needed to understand the course of metabolic processes in the organism of Russian sturgeon.

The most important components of the digestive system of Russian sturgeon are the intestine and the liver, which are formed by enterocytes and hepatocytes, respectively. When studying the peculiarities of the digestion processes of Russian sturgeon it is not possible to ignore the morphological parameters of the abovementioned groups of cells [5-7].

Thus, studies of the morphological parameters of enterocytes and hepatocytes are capable of providing the necessary for predicting the feasibility of using one or another diet in feeding juvenile fish.

\section{HIGHLIGHT OF THE EARLIER UNRESOLVED PARTS OF THE GENERAL PROBLEM. AIM OF THE STUDY}

The use of products of microbiological synthesis, namely, yeasts of various etiologies, has been widely used in sturgeon culture since the 1950s. However, baker's yeast, which is the most common in the world, is not a traditional dietary supplement for sturgeon (Acipenceridae) feeding [8]. Therefore, the aim of this work was to investigate the effect of different concentrations of inactivated baker's yeasts on the morphological parameters of the digestive system of Russian sturgeon (Acipenser gueldenstaedtii Brandt) fry. The dynamics of the morphological state of enterocytes and hepatocytes when feeding fish with dry baker's yeasts as an additive to the basic feed is an important indicator of the metabolic processes in the development of the organism of juvenile fish. In general, this provides an opportunity to predict the success of feeding Russian sturgeon fry and increase the effectiveness of this process.

\section{MATERIALS AND METHODS}

Studies have been carried out during the last few years (2016-2018), at the Experimental Fish Farm of Lviv Research and Experimental Station of the Institute of Fisheries of the National Academy of Agrarian Sciences of Ukraine.

The objects of study were yolk sac larvae of Russian sturgeon placed in a recirculating aquaculture system (RAS). The larvae were raised at a temperature of $16^{\circ} \mathrm{C}$. The dissolved oxygen content in water was $7.00-8.12 \mathrm{mg} / \mathrm{dm}^{3}$.

After 10 days of adaptation, sturgeon fry were divided into 3 groups of 1000 specimens each in order to determine the effect of inactivated baker's yeasts on productive characteristics. In the experimental group No. 1, the basic feed was supplemented with $10 \%$ inactivated dry baker's yeasts, while in the experimental group No. 2 , the basic feed was supplemented with $40 \%$ inactivated dry baker's yeasts. The diet of the control group of fish did not contain yeasts. Yeasts were manually introduced into the basic feed immediately after their inactivation by freezing in the freezer and before giving the feed to the test specimens.

The basic feed was the specialized starter feed "Inicio Plus" for sturgeons manufactured by "Biomar", which is widely represented on the Ukrainian market. The above-mentioned starter feed contains $58 \%$ of crude protein, $14 \%$ of crude fat, $10 \%$ of carbohydrates, $0.4 \%$ of fiber, $11.5 \%$ of ash and $1.7 \%$ of total phosphorus. 
The fish were fed six times during the day, taking into account their biorhythms, where $50 \%$ of the daily ration was given in the morning and evening, and the remaining feed was evenly distributed among four feedings in the afternoon. The daily control of growth rate, mortality, and teratological observations were made on the number and condition of specimens with physiological abnormalities.

For histological studies, a whole body of larvae was used. After anesthesia (by preparation «Propiscyn»), they were placed into a Buen solution (15 parts of a saturated aqueous solution of picric acid, 5 parts of formalin, 1 part of acetic acid) for 24 hours. After rinsing, the specimens were stored in $70 \%$ ethanol. Specimens were processed through alcohols and embedded in paraffin in accordance with the generally accepted technique. Histologic sections were stained with hematoxylin $\left(\mathrm{C}_{16} \mathrm{H}_{14} \mathrm{O}_{6} \cdot 3 \mathrm{H}_{2} \mathrm{O}\right.$, M.w. 356.33) and eosin $\left(\mathrm{C}_{20} \mathrm{H}_{8} \mathrm{Br}_{4} \mathrm{O}_{5}\right.$, M.w. 647.89052). Also, we used electron microscopes and photographs of the preparations obtained.

After feeding the Russian sturgeon fry with different concentrations of inactivated baker's yeasts, we analyzed the morphological structure of the most important organs, which was involved in the digestive processes - intestine and liver. This was done by analyzing the morphological parameters (shape, size etc.) of the state of enterocytes and hepatocytes, depending on the different concentrations of inactivated baker's yeasts fed by the of the Russian sturgeon fry.

\section{STUDY RESULTS AND THEIR DISCUSSION}

The histological sections of the intestinal specimens showed that experimental feeding with inactivated baker's yeasts affects the height of the brush border and the thickness of the mucopolysaccharide layer, and the height of enterocytes of the Russian sturgeon fry (Fig. 1).

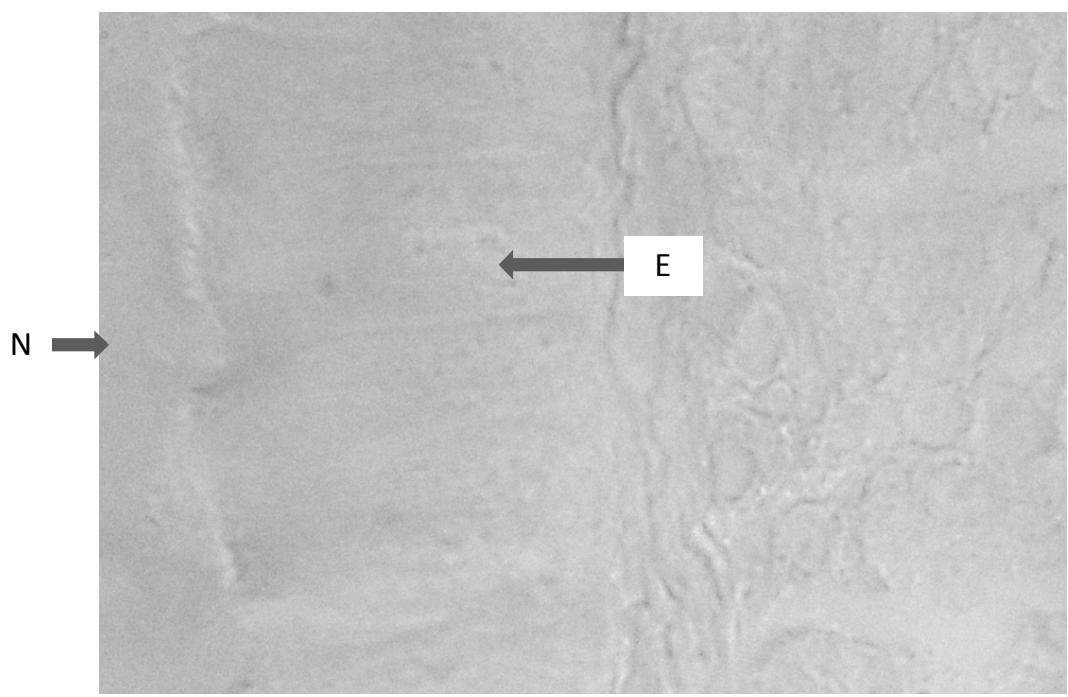

Fig. 1. Formation of the enterocyte surface in the intestine of the Russian sturgeon fry of the control group after the first day of experimental feeding ( $x$ 1600), E - enterocyte, $N$ - glycocalyx

During the experiment, significant changes in the shape and size of hepatocytes 
and the amount of glycogen accumulated in them were detected.

The ratio of the glycocalyx thickness to the enterocyte length in the intestine of the Russian sturgeon fry in the control and experimental groups is approximately the same and is $8.7 \pm 2.0 \%$. The surface of the mucopolysaccharide layer often contains settled groups of microorganisms that perform the function of mediated digestion by discharging own enzymes into the intestinal lumen. In general, in the control group, normal development of the intestine surface with a developed brush border is clearly visible after 24 days of the experiment (Fig. 2, 3).

The enterocyte nuclei are not located uniformly all cells: they are displaced closer to their apical part in $30 \%$ of cases, while others are located closer to the basal membrane. This reflects the intense processes of fission and growth in intestinal microvilli of Russian sturgeon fry.

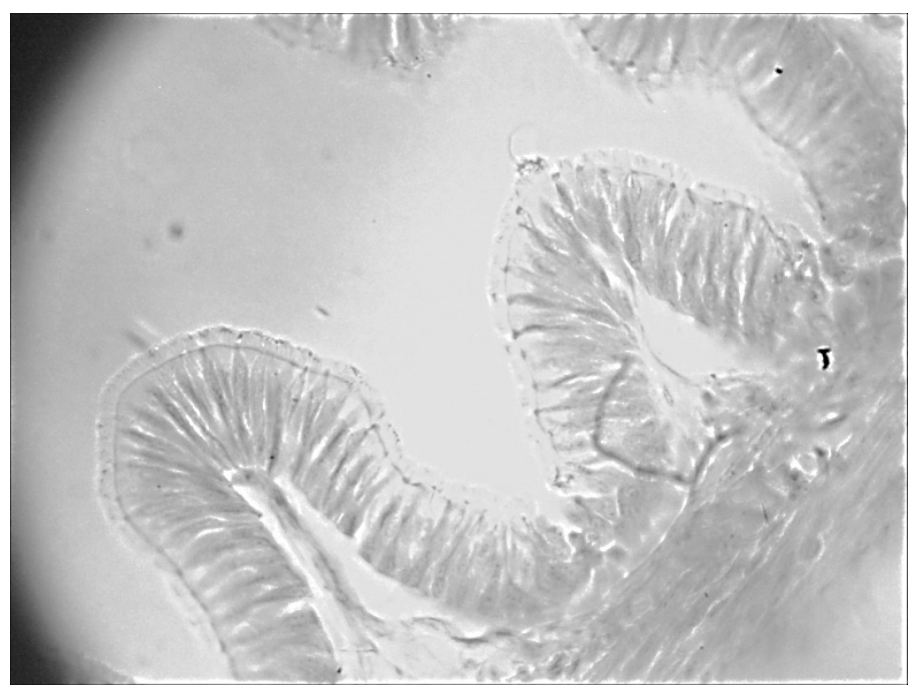

Fig. 2. Section of the mid-intestine of Russian sturgeon fry from the control group after 24 days of experimental feeding (x 160)

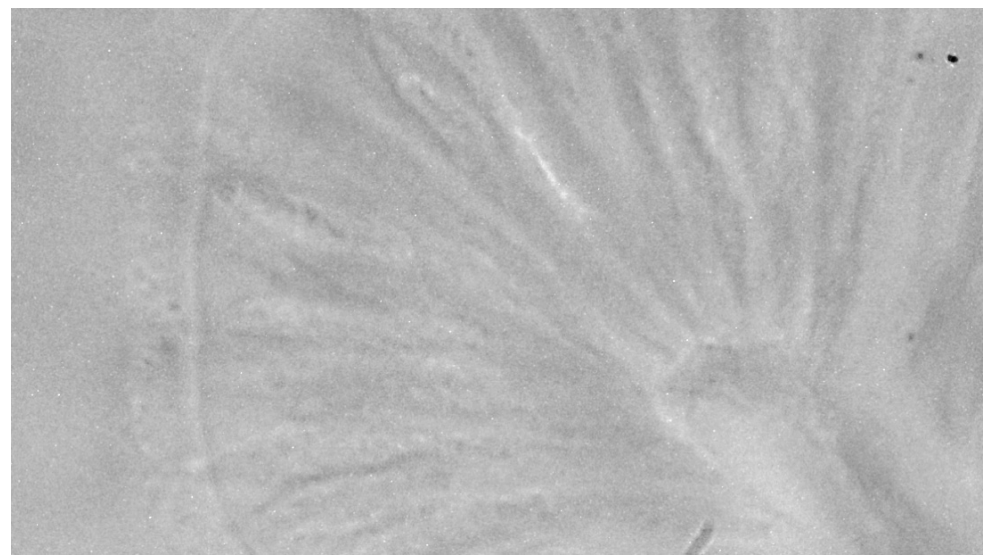

Fig. 3. Enterocytes on a microvillus in the mid-intestine of Russian sturgeon fry from the control group after 24 days of experimental feeding (x 1600) 
After 24 days of experimental feeding of sturgeon in the control group, the relative thickness of the microvillus layer increased significntly indicating an intensification of digestive processes (Fig. 4).

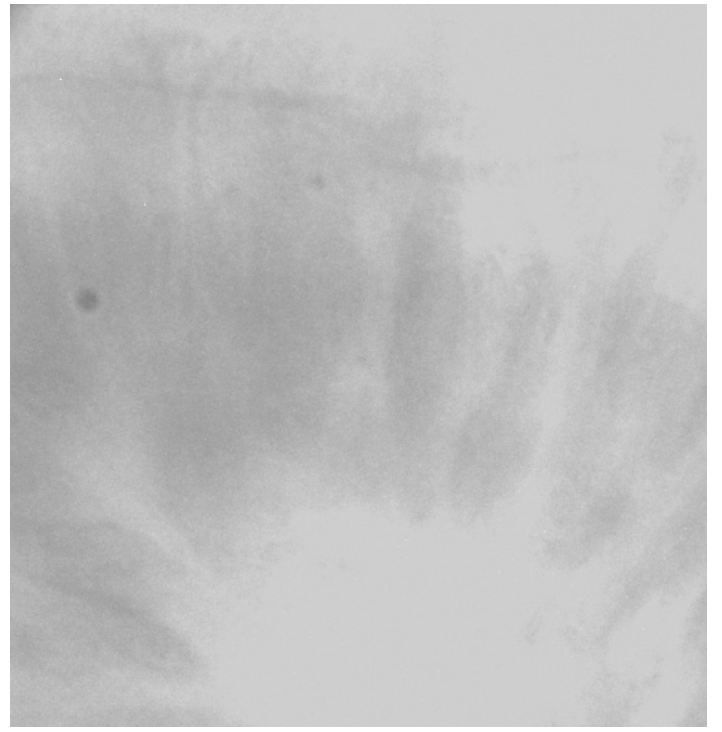

Fig. 4. Transverse section through the surface of an enterocyte in the midintesine of Russian sturgeon fry after 24 days of experimental feeding with a feed containing $10 \%$ of baker's yeasts (x 1600)

The average relative thickness of microvillus layer in the control group was 12.41 $\pm 0.89 \%$. This natural phenomenon is also associated with an increase in the activity of membrane digestion, which depends on the thickness of the glycocalyx, in which both own intestinal enzymes and those synthesized in enterocytes are absorbed.

Promising results were obtained in a group of Russian sturgeon fry fed with $10 \%$ baker's yeast. In this group, the relative thickness of the microvillus layer covered with glycocalyx was $17.16 \pm 2.26 \%$.

The presence of inactivated baker's yeasts in the feed seems to contribute to an increase in the thickness of glycocalyx that in general has a positive effect on digestive processes. One of the reasons for this is the increased likelihood of a higher number of loci for symbiotic microorganisms that play an active role in extracellular digestion.

Enterocytes in sturgeon fry fed with a feed containing $40 \%$ baker's yeasts had a normal appearance with distinct nuclei displaced in the basal direction (Fig. 5).

There are no phenomena of enterocyte desquamation that indictes a positive effect of the experimental supplementation with baker's yeasts on the digestive tract of Russian sturgeon fry.

The microvillus layer was not always uniform and formed a wave-like structure. Its thickness relative to the height of the cell was $11.31 \pm 1.57 \%$. The average height of the mucopolysaccharide layer was lower than the control results of $8.9 \%$. The enterocyte nuclei were located mostly in the basal part of these cells, with a small percentage in their apical part. 
Fig. 5. Transverse section through enterocyte surface in the mid-intestine of Russian sturgeon fry after $\mathbf{2 4}$ days of experimental feeding with a feed containing $40 \%$ of baker's yeasts ( $x \times 1600)$

The inhomogeneous and lower height of glycocalyx indicates a deterioration of digestive processes and, consequently, of absorption. It also negatively affects the location of symbiotic organisms.

Thus, feeding with the strater feed containing $40 \%$ of baker's yeasts during 24 days did not improve the digestive process and therefore is inappropriate. Instead, feeding with the strater feed containing $10 \%$ of yeasts during the same period of time positively affected the morphological parameters of the digestive tract resulting in an increase in the glycocalyx layer and microvillus height by $38.2 \%$ relative to the control parameters. This creates a positive precondition for optimizing the digestive processes and, as a consequence, the growth of the Russian sturgeon organism.

Let's consider the effect of experimental feeding with the use of baker's yeasts on hepatocytes of Russian sturgeon fry. Fig. 6 shows their hepatocytes at the beginning of the experiment.

The hepatopancreas of Russian sturgeon after metamorphosis in the juvenile period contains a large number of fat vacuoles and glycogen grains that plays an important role of energy depot. In the future, with an increase in the activity of lipolytic processes, the amount of fat in the liver will decrease. However, the quality of fats in feeds consumed by sturgeon juveniles plays an important role during this period. In our case, the starter feed contained $15 \%$ of fat, which led to its intense accumulation in the liver. Fig. 6 shows clear large hollow vacuoles among hepatocytes.

It is known that accumulation of lipid drops in liver tissues at the beginning of active nutrition is a temporary phenomenon. The reason for this may be the low activity of lipolysis and slow transport of fats. However, during active feeding, this situation may change rapidly. To investigate this aspect, let's consider the morphological structure of the liver of Russian sturgeon fry after 24 days of experiment (Fig. 7). 


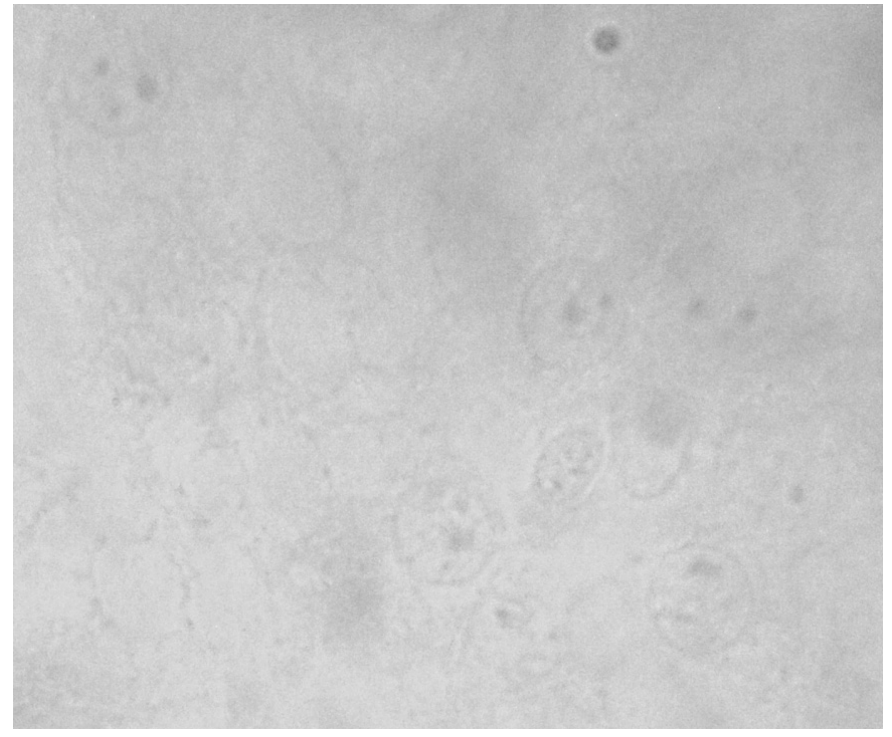

Fig. 6. Hepatocytes of Russian sturgeon fry after the first day of experimental feeding with noticeable fat vacuoles $(x \mathbf{1 6 0 0})$

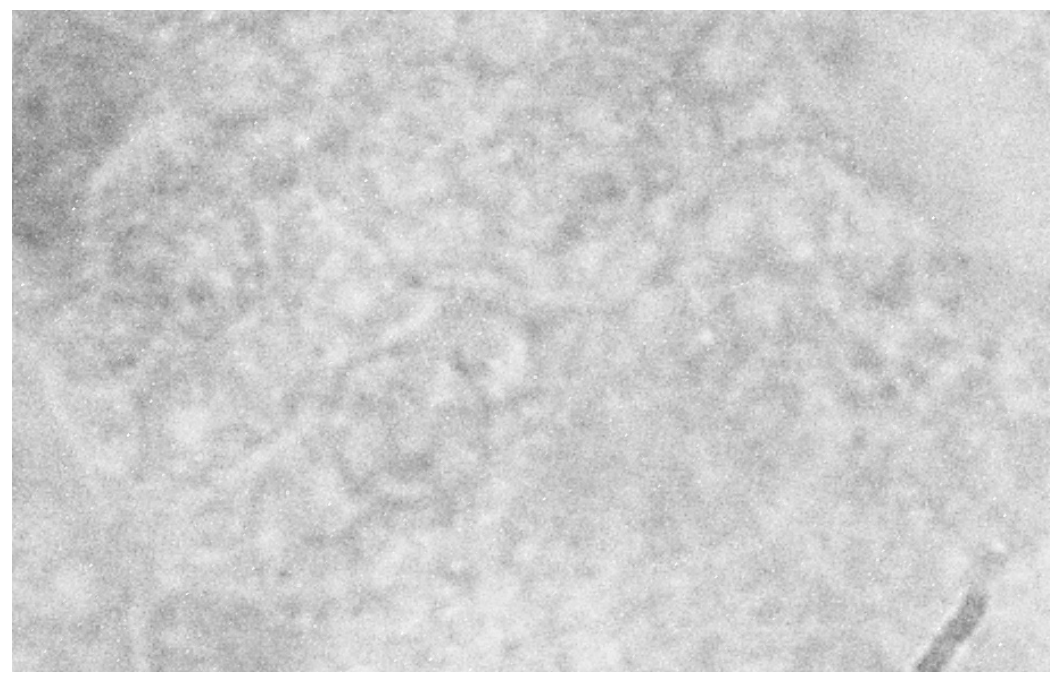

Fig. 7. Hepatocytes of Russian sturgeon fry of the control group after 24 days of experimental feeding filled with vacuoles contaoning accumulated substances $(x$ 1600)

Figure 7 shows that with a relatively stable density of lipid vacuoles in liver tissues, their size decreased by $23 \%$ relative to the state at the beginning of the experiment. Here, there is a normalization of lipid metabolism, which was confirmed by our studies of the activity of lipolytic enzymes (lipases) $[9,10]$.

Let's consider the morphological structure of hepatocytes when exposed to different concentrations of baker's yeasts added to the basic starter feed for sturgeon fry. Fig. 8 shows a fragment of the liver of this fish fed with a feed containing $24 \%$ of baker's yeasts during 24 days. 


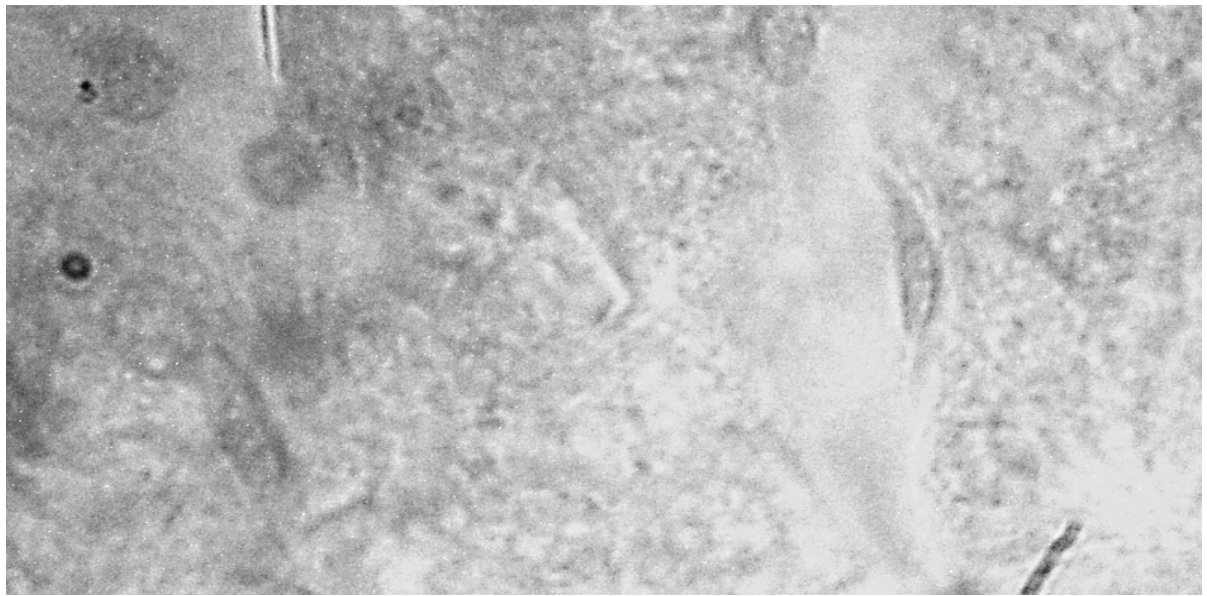

Fig. 8. Hepatocytes of Russian sturgeon fry of the control group after 24 days of experimental feeding with $10 \%$ of baker's yeasts $(x$ 1600)

Normally developed hepatocytes are visible near connective cells of the hepatic stroma. By size - they are similar to those in the control group of fish. In cells, there are noticeably small granules of accumulated substances that is normal for this stage of development. There are no signs of excessive fat accumulation beyond hepatocytes. Fat cells are present, but they are small in size. Their number is lower by $12 \%$ relative to that in the control group of fish. This concentration of yeasts seems to have a positive effect on the morphological structure of the liver, and, accordingly, on the digestion processes.

Let's consider the structure of hepatocytes in the experimental group of fish fed with a starter feed containing $40 \%$ of inactivated baker's yeasts (Fig. 9).

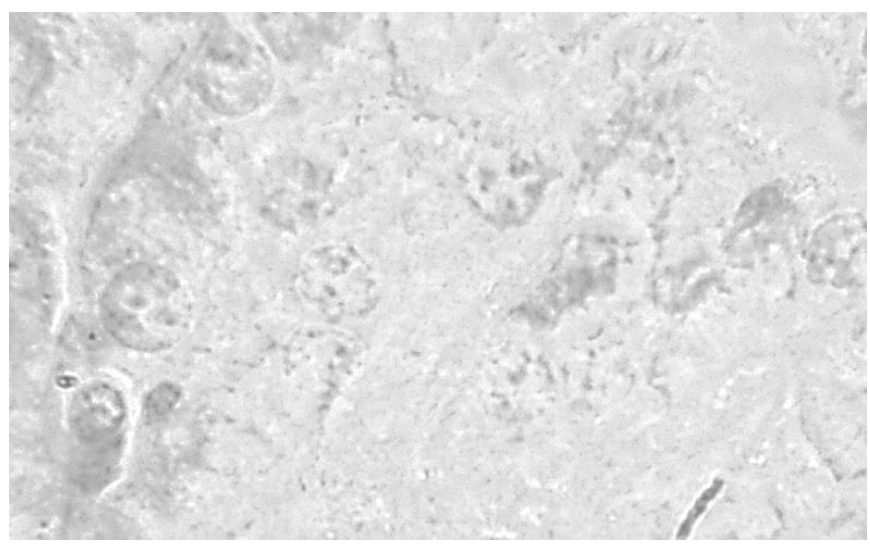

Fig. 9. Hepatocytes of Russian sturgeon fry of the control group after 24 days of experimental feeding with a feed containing $40 \%$ of baker's yeasts (x 1600)

Fig. 9 shows that the size of hepatocytes is slightly increased compared to the control group. Their average length is $611,21 \pm 241.71 \mu \mathrm{m}$, which is $23 \%$ higher than the maximum length of hepatocytes in the control group. Fat vacuoles are presented in the form of small grains that are chaotically located among hepatocytes. Obviously, this 
is due to insufficient amount of fat in the diet and its reserve use from the liver. In general, there are many inclusions in the hepatocytes of fish in the experimental group. Thus, the use of $40 \%$ yeasts in the diet ssems to lead to metabolic changes that are associated with the utilization of nutrients in the liver and ieffective energy costs.

It is important to emphasize that the toxic effect of high concentrations of inactivated baker's yeasts in the starter feed for Russian sturgeon was not confirmed.

\section{CONCLUSION AND PERSPECTIVES OF FURTHER DEVELOPMENT}

Consequently, the use of dry baker's yeasts inactivated by cold as a biologically active supplement to the basic feed is a promising trend in sturgeon culture.

Analysis of the morphological structure of enterocytes and hepatocytes of sturgeon fry in conditions of feeding with feeds containing $10 \%$ and $40 \%$ of baker's yeasts by weight for 24 days suggests a positive effect of low baker's yeasts concentration. First of all, the positive effect of using baker's yeasts manifests in a $38.4 \%$ increase in the absorption surface of enterocytes. Secondly, there is an improvement in the localization in glycocalyx both for enzymes and for symbiotic microorganisms that play an active role in extracellular digestion. Thirdly, the optimal regulation of lipid metabolism of the liver and the maintenance of its trophic structure was noted.

All this defines the relevance of further research on the selection and scientific justificstion of the optimal concentration of baker's yeasts, which would be appropriate to be used in feeding of Russian sturgeon fry.

\section{BIBLIOGRAPHY}

1. Волкова И. В. Особенности функционирования пищеварительной системы рыб различных трофических групп : автореф. дис. на соискание уч. степени докт. биол. наук : спец. 03.03.01 «Физиология». Астрахань, 2010. 44 с.

2. Бедняков Д. А. Структурно-функциональные особенности мембранного пищеварения у осетрообразных видов рыб и их гибридов : автореф. дис. на соискание уч. степени докт. биол. наук : спец. 03.03.01 «Физиология». Астрахань, 2014. 44 с.

3. Бедняков Д. А., Мартьянов А. С. Сравнительный анализ воздействия рН среды на уровень активности пищеварительных ферментов русского осетра, ленского осетра и их гибрида с помощью неметрического многомерного шкалирования // Вестник АГТУ. 2013. № 2. С. 145-149.

4. Бедняков Д. А., Неваленный А. Н., Новинский В. Ю. Исследование некоторых характеристик ферментов, обеспечивающих процесс мембранного пищеварения у веслоноса и стерляди // Физиологические, биохимические и молекулярно-генетические механизмы адаптаций гидробионтов : Bсерос. конф. с междунар. участием : матер. Борок, 2012. С. 36-39.

5. Пегель В. А. Физиология пищеварения рыб. Томск : Том. гос. ун-т, 1950. $200 \mathrm{c}$.

6. Строганов Н. С. Экологическая физиология рыб. Москва : МГУ, 1962. 444 с.

7. Справочник по физиологии рыб / Яржомбек А. А. и др. Москва : Агропромиздат, 1986. 192 с.

8. Симон М. Ю. Використання кормових дріжджів у годівлі осетрових видів риб (Acipenseridae) (Огляд) // Рибогосподарська наука України. 2015. № 4 (34). С. $100-126$. 
9. Симон М. Ю. Особливості окисних процесів у осетрових видів риб (Acipenseridae) (Огляд) // Рибогосподарська наука України. 2016. № 1 (35). C. $106-126$.

10. Симон М. Ю., Грициняк I. І., Забитівський Ю.М. Вплив пекарських дріжджів на ліпідний обмін молоді російського осетра // Рибогосподарська наука України. 2018. № 2 (44). С. 137-143.

\section{REFERENCES}

1. Volkova, I. V. (2010). Osobennosti funktsionirovaniya pishchevaritel'noy sistemy ryb razlichnykh troficheskikh grup. Extended abstract of doctor's thesis. Astrakhan'.

2. Bednyakov, D. A. (2014). Strukturno-funktsional'nye osobennosti membrannogo pishchevareniya u osetroobraznykh vidov ryb i ikh gibridov. Extended abstract of doctor's thesis. Astrakhan'.

3. Bednyakov, D. A., \& Mart'yanov, A. S. (2013). Sravnitel'nyy analiz vozdeystviya pH sredy na uroven' aktivnosti pishchevaritel'nykh fermentov russkogo osetra, lenskogo osetra i ikh gibrida s pomoshch'yu nemetricheskogo mnogomernogo shkalirovaniya. Vestnik AGTU, Seria: Rybnoe khozyaystvo, 2, 145-149.

4. Bednyakov, D. A., Nevalennyy, A. N., \& Novinskiy, V. Yu. (2012). Issledovanie nekotorykh kharakteristik fermentov, obespechivayushchikh protsessov membrannogo pishchevareniya u veslonosa i sterlyadi. Fiziologicheskie, biokhimicheskie $i$ molekulyarno- geneticheskie mekhanizmy adaptatsiy gidrobiontov: Vserossiyskoy konferentsiya s mezhdunarodnym uchastiem. Borok, 36-39.

5. Pegel', V. A. (1950). Fiziologiya pishchevareniya ryb. Tomsk: Tom. gos. un-t.

6. Stroganov, N. S. (1962). Ekologicheskaya fiziologiya ryb. Moskva: Izd-vo MGU.

7. Yarzhombek, A. A., Limanskiy, V. V., \& Shcherbina, T. V. et al. (1986). Spravochnik po fiziologii ryb. Yarzhombek, A. A. (Ed.). Moskva: Agropromizdat.

8. Symon, M. Yu. (2016). Osoblyvosti okysnykh protsesiv u osetrovykh vydiv ryb (Acipenseridae) (Ohliad). Rybohospodarska nauka Ukrainy, 1(35), 106-126.

9. Symon, M. Yu. (2015). Vykorystannia kormovykh drizhdzhiv u hodivli osetrovykh vydiv ryb (Acipenseridae) (Ohliad). Rybohospodarska nauka Ukrainy, 4(34), 100126.

10. Symon M. Yu., Hrytsyniak, I. I., \& Zabytivskyi, Yu. M. (2018).Vplyv pekarskykh drizhdzhiv na lipidnyi obmin molodi rosiiskoho osetra. Rybohospodarska nauka Ukrainy, 2(44), 137-143. 